\title{
The Community Library as Site of Education and Empowerment for Women: Insights from Rural Uganda
}

Shelley KaTHLEEN JONES

Department of Language and Literacy Education, University of British Columbia, Canada

Community libraries in developing countries can be important sites of knowledge exchange and acquisition for women with little or no formal education living in communities characterized by extreme poverty and gender inequities. As locally managed and operated institutions, specific needs identified by community members shape their mandates, activities, and types of resources. Community libraries also offer a "neutral" space where women can safely gather and independently or collectively pursue learning in areas of relevance and interest to them. This paper explores the impact of Kyato Community Library (KCL) on women's lives in a rural Ugandan context. It considers the questions: i) What valuable educational opportunities does KCL provide for girls and women who have been prevented from attaining adequate formal schooling?; and ii) What additional services, opportunities and qualities could KCL provide to engage girls and women in these educational opportunities? The paper argues that with careful attention paid to women's literacy needs and desires, local context, appropriate resource acquisition and community-minded personnel, community libraries can promote and support women's literacy and personal development, enabling them to cultivate capabilities needed to engage more fully on equal terms in their societies.

\section{Introduction}

This paper examines the impact of a community library on the literacy development and engagement of a group of women living in rural Uganda. Although community libraries are not yet commonplace institutions in Uganda, this article shows that they can perform multiple functions as alternative sites of knowledge acquisition for women who have traditionally had limited opportunities for schooling. Community libraries can constitute safe and empowering educational environments where women's learning and personal development is supported and encouraged, and where women feel a sense of belonging and ownership. At their best, community libraries constitute a portal towards gender equity in communities, offering a physical place and educational environment in which women can interact, learn, and work towards future goals. However, there is still much to learn about how community libraries can maximally serve marginalized girls and women in an educational capacity.

Based on research at Kyato Community Library (KCL) [1] in Kyato Village in south-western Ugan$\mathrm{da}$, this paper argues that with careful attention paid to location and personnel, as well as responsiveness to community contexts and happenings, community libraries can play an important role in the development and support of women's literacy in developing country contexts. It explores both the current limitations as well as the enormous, transformative educational potential of community libraries for girls and women. This is followed by some recommendations for how community library programming can be designed in such a way as to maximize its positive impact in the lives of women and girls living in rural contexts in developing countries that share commonalities with Uganda. 


\section{Background to the study}

This study on community libraries forms part of a larger study, begun in 2003 by Bonny Norton and Maureen Kendrick of the University of British Columbia. The research design of the larger project involves longitudinal, qualitative multiple-case studies of a select number of women and adolescents in three sites in Uganda. Across all three sites, this research seeks to investigate the complex relationship between literacy and development, and to better understand women and girls' participation in literacy practices associated with development, although the research foci and questions vary in the different contexts. The indicators of development that are central to this research include health, education, work, local and national government, transportation, and leisure. Findings from the larger research project are being disseminated in diverse contexts (Jones 2008; Jones \& Norton 2007; Jones \& Norton in press; Kendrick \& Jones 2008; Kendrick et al. 2006; Kendrick et al. forthcoming). PhD research constitutes one part of this larger study, and data drawn from $\mathrm{PhD}$ fieldwork (August 2004 - August 2005) in Kyato Village, south-western Uganda, forms the basis for this paper.

\section{Theoretical perspectives}

The community library has immense potential to actively engage girls and women who have had limited or no formal schooling in educational opportunities. It can provide a space and environment that supports their empowerment, personal development, and ability to engage more fully in their societies:

[Evidence points to] the dynamic creativity and potential as well as the challenges for the involvement of libraries in creating literate environments for lifelong learning. It also shows that investing in books and libraries is at the heart of educational reform, literacy enhancement and sustaining literacy skills for life, leading subsequently to development and poverty reduction. By providing equitable access to information for all, libraries encourage critical citizenship in a global democratic society. (Krolak 2005, 13)

However, in order for community libraries to meet the literacy needs and desires of women who have demanding lives, numerous responsibilities and limited time and mobility, it is necessary to develop innovative pedagogical approaches that are centred - both in terms of physical space and programming content- within the community to which these women belong. Programs must be developed to cultivate capabilities and knowledge to support women in realizing their personal aspirations and well being (Nussbaum 2003a/b; Robeyns 2006; Robinson-Pant 2004; Saito 2003; Sen 1999; Subrahmanian 2005; Unterhalter 2005). Literature demonstrates that the Western "passive" (Mostert 1998) model of the library is highly ineffectual in non-urban African contexts, and "its poverty as a paradigm for information service in Africa has been proven by the test of time" (Sturges $2001,47)$. Libraries have been typically perceived as monolithic, intimidating colonial institutions that require high levels of literacy and education as a precondition of use and membership (Nawe 2001). Particularly in rural areas, with large populations that have received little, if any education, there is an urgent need for the establishment of a new library "paradigm" (Mostert 1998) that strives to meets specific needs of communities (Nawe 2001; Sturges 2004; Sturges \& Gooch 2006).

Community libraries must be seen as part of the community and must actively promote their services to become valued and valuable local institutions: "Modern libraries are unfolding the community's learning potential by providing information on community issues, such as health, employment, continuing education and local history" (Krolak 2005, 6). Core elements of this paradigm would include: integration (e.g., textual, oral) of Indigenous knowledge and traditions (Nawe 2001; Sturges 2004), community-based determination of resources and programmes (Nawe 2001; Mostert 1998; Sturges 2004); pro-active community outreach (Nawe 2001); and local management where community members shape the mandate as well as the nature of the activities, and the focus of resources (Aitchison 2006; Dent \& Yannotta 2005; Mostert 2001). In this way, community libraries offer opportunities for the active and meaningful learning engagement of their patrons. The proactive outreach and community engagement aspects of the community library, combined with personnel that openly welcome and encourage participation of all community members is likely to have a profound effect on community learning in general (Nawe 2001). 


\section{Research contexts and participants}

This article explores the Kyato Community Library, located in Kyato Village, Masaka District. KCL is situated in a village that borders a trading centre that is approximately seven miles from the nearest town centre, Banda, in south-western Uganda. Poverty in this rural area of the country is endemic and acute. Most families survive by subsistencelevel farming, with small incomes sometimes earned through men's employment (e. g., as labourers or in other occupations, such as tailoring or driving taxis), the sale of crafts such as mats and baskets made by women, or the sale of extra food grown in the family gardens. The official per capita income is less than $\$ 1$ US per day, although many families in rural areas such as Kyato Village live on substantially less (UBS, 2002). Malnutrition, disease, and poor living conditions are widespread, and it has been one of the areas in the world hardest hit by the HIV/AIDS pandemic. There is no electricity in this area and although running water has been available since 2005 for a cost, very few households can afford to pay for it.

KCL began as a box of books in 1999. In 2002, with the support of a UN $1 \%$ Fund grant, KCL was opened, a building that seats 28 patrons and houses over 1,000 books. KCL is located on the grounds of Kyato Secondary School, although the two institutions are separately managed. In 2004, KCL received further funding for solar panels, and thus was one of the few buildings for miles around with power. This enabled students and community members to read and study at night, as well as allowed for the use of a couple of computers, a printer, rechargeable batteries, and the powering of cell phones (for a small charge that contributed to the library's operations). KCL quickly became the hub of Kyato and surrounding villages as a place to peruse books and newspapers, attend workshops, study, and attend important community and club meetings. It has also become an important place of learning, especially for girls and women, as discussed below.

During the course of carrying out $\mathrm{PhD}$ research related to adolescent girls and secondary schooling in rural Uganda, the author became aware of the educational and literacy needs of women in the community, as well as their intense desire for learning and their strong belief that education could lead to improved socioeconomic conditions, independence and empowerment. She also realized the important role that a community library could play in offering a socially-sanctioned site of knowledge exchange and acquisition for girls and women living in rural communities who sought educational opportunities. As a result, a secondary study on the impact of the community library on their literacy development and engagement was conducted and forms the basis of this paper.

\section{Methodology}

The fieldwork for this study took place from August 2004 to August 2005, during which time the author worked closely, in a number of capacities with Kyato Secondary School (KSS), KCL and the Kyato community. She attempted to provide and participate in as many varied contexts as possible in which to interact with community members, and integrated into the community by teaching and cofacilitating clubs at KSS, visiting women's and other community groups, visiting local primary schools, health clinics and other institutions, and teaching the women's literacy class at KCL. Mr. Daniel Ahimbisibwe [2] (from hereon referred to as "Dan"), one of the librarians at KCL, served as an invaluable research assistant and translator throughout my fieldwork. (Dan had, in fact, been teaching the women's literacy class before the author's arrival, and continued after the author's departure.) Data collection methods with the women included videotaped interviews, questionnaires and focus group discussions.

\section{Research questions}

The assumption was that community libraries have a potentially powerful role to play in the lives of many girls and women in rural African contexts, such as in Uganda, where gender inequities have severely limited their education (and life) opportunities. The research questions addressed in this study are:

1. What valuable educational opportunities does KCL provide for girls and women who have been prevented from attaining adequate [3] formal schooling?

2. What additional services, opportunities and qualities could KCL provide to engage girls and women in these educational opportunities? 


\section{Findings and discussion}

This section discusses the findings with respect to the three research questions.

\section{Educational opportunities}

This study found that the community library offered multiple educational opportunities for girls and women due to its location, its personnel, its programs and its resources.

\section{Location}

KCL was located within a short walking distance (less than a mile) for most of the women who attended the adult literacy classes. The close and central location of the library was an extremely important factor in terms of its accessibility for women for a number of reasons. Because of their heavy domestic workloads, women have very limited time available for other activities; so, long commutes to a library would render it essentially inaccessible. Women are also at risk of being sexually assaulted if they must travel long distances alone; thus, it is unlikely they would be able to use a library located a long distance from their home. An additional constraint imposed on women's mobility was by their husbands, stemming from the men's suspicion that their wives might be engaged in clandestine activities while they are away from the house. According to Julia: "The problem is like some men don't believe that the women are going to the seminars ... the think they are going somewhere different." Thus, literacy classes held in a public, central space mitigates men's suspicion of their wives' activities.

\section{Personnel}

As Nawe (2001) insists, the personnel of a community library are central to they ways in which community members respond to it: "Persons performing the work have a profound effect both on how libraries/information centres operate and on how communities perceive these institutions. The relationship that exists between users and information specialists is crucial" (Nawe 2001, 143). KCL had one male full-time librarian, Dan, who lived in the community; one female part-time (three days a week) librarian, who lived some distance from the community; and several "library scholars". Dan had had previous library experience in Kampala, the capital city, and was originally from a different part of the country, but he had been living and working in Kyato Village for two years when the study began. The part-time female librarian also had prior experience working in a library and had also been working at KCL for about two years. Although both librarians were not originally from the local community, their previous experience working in libraries, their secondary level education, and their English and Luganda (the mother tongue of most people living in this region of Uganda) language abilities were important attributes in this role.

In addition to the two librarians, a number of "library scholars" interned at KCL. The "library scholars" were promising students from Kyato Secondary School (KSS) who had been chosen by a committee comprised of KCL and KSS staff. These students received scholarships, or internships, that paid their school fees while they attended KSS in exchange for a commitment of several hours a week working at the library. The awards were divided equally between girls and boys, reflecting KCL's commitment to gender equity and promoting opportunities for girls and women.

The librarians sought out opportunities to engage community members by hosting various workshops and public meetings. These events brought community members to the library to learn about health issues, community happenings, etc. It also hosted events for specific groups, such a workshop on innovative teaching methods for local primary and secondary school teachers. In terms of the active participation of women and girls, however, perhaps the most important aspect of the KCL personnel was their approachability and sincere interest in the women's literacy needs and aspirations.

\section{Materials}

In 1999, KCL began as a modest collection of 97 books. In 2004/05, when this study was undertaken, it had a collection of almost 2,000 books and other types of reading materials. As $\mathrm{KCL}$ worked to attract as many members as possible, this collection was accordingly diverse. Since its inception, KCL amassed as many books and other literacy resources as possible in the local languages, Luganda and Ki-Swahili, in order to both provide access to information and literature to accommodate those who read in these languages (or for those whom had little, if any, English reading ability), as well as 
to support the maintenance of these languages. There was a wide range of materials - over 200 titles - ranging from children's stories, to novels, to reference materials, in Luganda, and about 20 books in Ki-Swahili. In addition, the library had a daily subscription to 'Bukkedde,' the Luganda regional newspaper.

In addition to the Luganda and Ki-Swahili resources, there was a large collection of English books and resource materials - ranging from text books, to classic and contemporary novels, to reference manuals for agriculture, to books and pamphlets on health issues. The library also had a daily subscription to 'New Vision,' one of the two national English language newspapers. The women stated that the reading materials they felt were most important included books on farming, health, and language, newspapers (English and Luganda), novels (English and Luganda), and they thought KCL had a sufficient collection of resources on these topics.

\section{Community engagement}

KCL hosted a number of workshops in which health professionals presented seminars on important health-related topics, which were popular and generally well attended (i.e. - by 10-20 people). Again, interestingly, it was women who constituted the vast majority of participants in these workshops. There were few, if any, other places in the community that could accommodate the kinds of workshops and seminars that were offered by the library. In addition, there were resources at the library that provided additional information to corroborate that of the workshops/seminars. During interviews with the women that participated in this study, many of them advocated for more workshops - on health, farming and business, in particular.

\section{Adult English/literacy instruction}

Adult English/literacy instruction had been offered at KCL since 2002, in the form of classes as well as individual tutoring. Although all adult members of the community had been invited and encouraged to take advantage of adult literacy activities, it was, interestingly, almost exclusively women who regularly sought instruction and attended the classes. These women strongly believed that literacy and education were critical to women's overall wellbeing and empowerment. During an interview with
Louise, a 22-year old single mother, the topic of cultural gender inequities arose. When asked if she thought that improved literacy abilities could help women to overcome these inequities, Louise said:

[If you are literate] even if you are depressed at home, or you get any problem, you can go ahead in courts of law, and go there and talk to people ... because you can be able to read and know, like, the rules and the what ... but when you are not educated, you just die there because you don't know ... [translated from Luganda]

One-on-one literacy instruction: vignettes of two young women in the community

Two young women in the community, profiled below, approached KCL's male librarian, Dan, to teach them basic literacy skills. Dan agreed and committed several hours a week to help both cultivate literacy abilities in both Luganda and English.

\section{Monica}

Monica, a 23-year old woman, was married with two young children. Monica had wanted a college level education, but was able to attend school only up to Primary 5, due to the poor financial situation of her family. However, Monica's determination to continue with her education motivated her to become involved with KCPL from the beginning, right from the early fundraising stage. (In fact, she provided her own home furniture to be used for the library's opening ceremony.) In 2004, Monica approached Dan, saying that she wanted to learn how to read and write in English, as well as Luganda, and Dan agreed to spend three or four hours a week tutoring her.

When asked in an interview what she thought was the best thing about the library, Monica answered (in English): "I read and understand ... and understand how to speak ... to write [in English], and know what is going on". When she was asked why she was taking the adult literacy class, she said: "to understand how to speak English." When asked why that was important to her; how learning English would help her in her daily life, and she laughingly retorted: "Now this time I'm speaking to you!"

\section{Jessica}

Another young woman, Jessica, whom Dan had been tutoring, has never gone to school. She was illiterate in both Luganda and English, and had extremely minimal English-speaking skills. Jessica 
had experienced a great deal of hardship and abuse in her life, stemming from the fact, she believes, that she was illiterate and uneducated. She was determined to change this. Jessica approached Dan, requesting that he teach her how to read and write in both Luganda and English, as well as speak English. Again, Dan committed a few hours a week to working with Jessica. Less than two years later, Jessica was able to read and write at a beginner level in both Luganda and English, and had a very solid grasp of basic spoken English. This is an excerpt from her interview:

Shelley: Did you know how to read before you [started going] to the library?

Jessica: No.

Shelley: How did you learn how to read?

Jessica: Mr. Dan helped me a lot ... now I can try Luganda a bit, and English.

Shelley: So you learned both Luganda and English - reading and writing?

Jessica: Yes.

Shelley: What kinds of things do you like to read?

Jessica: Novels and newspapers.

Interestingly, both Monica and Angela were the only two women - out the eight interviewed - who chose English with which to engage in as much as the interview as possible, even though a translator was available.

Both Monica and Jessica regularly attended lessons with Dan at the library. Dan also encouraged Monica and Jessica to work together, independently of him, and the two young women developed a strong learning/teaching relationship. They were both unwaveringly committed to becoming literate in English and Luganda, and acquiring the kind of education that would enable them to make changes in their lives. They were both interested in developing the literacy abilities they needed to begin small businesses as well as understand more about the world (i.e., reading and understanding Luganda and English-language newspapers). Monica and Jessica spent a large amount of time reading and studying independently in the library to reinforce what they learned in their lessons with Dan. In addition, both were committed participants in the adult literacy classes and hoped to write their Primary Leaving Examinations eventually. Monica also began to study math and science with another teacher, with the goal of proceeding to secondary level education (and perhaps beyond).

\section{Adult literacy classes}

The eight women who regularly attended the adult literacy classes ranged in age from 22 to 53 years old. Two were single mothers, one was single (separated from her husband and child), one was a widow raising several orphaned grandchildren, and four were married with several children. None of the women had been to secondary school, and few had completed primary school, although all of them stated that they had wanted to complete Senior 4 (equivalent to Grade 11) as a minimal educational level. Two had wanted to become doctors, two had wanted to become teachers, and the others had had hopes of having professional careers, or at least skills with which to be qualified to work at salaried jobs and be financially independent. At the time of this study, seven of these women were primarily engaged in subsistence farming, and one earned a minimal wage cooking and caring for orphans at a local primary school.

Although these women's educational and career ambitions had been thwarted early on by the financial inability of their parents/guardians to provide schooling for them, the adult literacy class provided an opportunity for them to work towards their educational goals, and learn how to enhance and become more productive in the work they were doing. They believed literacy was critical to women's empowerment. When asked during individual interviews (May 2005) what the women believed if/ why literacy was important, some responses (translated from Luganda) were:

- "For development, even the government can implement its programs because of literacy"

- "In this world we are living in, there is nothing you can do without literacy."

- "Education is important because even house girls needs education to read instructions, make lists - basically earn a living any way."

- "Even if you are depressed at home, or you get any problem, you can go ahead in courts of law, and go there and talk to people ... because you can be able to read and know, like, the rules and the what ... but when you are not educated, you just die there because you don't know ..."

- "It's teaching them to read and write and to know, and that's the door to so many things."

The women all agreed that the adult English/ literacy classes were useful to them, and identified 
some of the most important aspects as (translated from Luganda):

- "To know how to get the information, read it and interpret it"

- "To learn how to run a business"

- "I can understand more things I didn't get a chance to learn, and to understand like sometimes when there is news in English, I want to understand what is happening around the world and to communicate with other people that doesn't understand local languages ... and I can be able to analyse things".

- "To learn more and to be able to understand things"

- "To learn English because important ceremonies here are conducted in English, and then you cannot get [understand] the speeches ... and even office communication."

\section{Safe, accessible space for women}

The "community" aspect of the community library is key to its effectiveness as an institution in rural areas where gender inequities prevail. As Mlama explains, "Since most of the gender constraints to education emanate from the deeply entrenched cultural values, attitudes and practices of the parents and the community opinion leaders and the community members in general, it requires the community's effort to change them." (2005, 5). Therefore, a library that is rooted deeply within the community and enjoys legitimacy under the eyes of community leaders will be able to extend its reach further.

In patriarchal cultures, such as in Uganda, where women tend to have limited freedom and mobility due to both domestic demands and gender inequities, men often have the authority to deny their wives participation in extra-household activities. One of the adult literacy participants, Julia, stated: "In some relationships, men doesn't given women opportunity, like to go for more education ... to go to workshops, and even go to work". Therefore, to help overcome such resistance by men to women's education and engagement with community activities, it is important that any site of learning or gathering be not only centrally located, but also socially-sanctioned as an acceptable, neutral gathering place for females, and non-threatening to men. This openness and universal accessibility helps ensure that the educational programming is transparent.

KCL had a particularly significant impact on women in the community because it was perceived as being an inherently "neutral space" - a place that belonged equally to all its members. In a safe space where women are supported to pursue various learning objectives according to their needs and interests, whether simply being able to read the daily paper or to get specific information related to starting a small business or responding to a health concern, learning leads to empowerment. In addition to coming to the library to read and attend adult literacy classes, the women said that they use the library as a place "to meet others and have discussions" and "[to] interact with other people".

This kind of space, while valuable in the services and resources it provides for women, also subtly challenges traditional gender hierarchies and roles. The women who used the library expressed feeling a sense of ownership over the space, and said they found KCL "comfortable", and "the right place" to learn. According to Gloria: "it is at the library, she can get free time to read, but at home, during the daytime, she cannot sit and read, because there is something always to do."

\section{What additional services, opportunities and qualities could KCL provide to engage girls and women in these educational opportunities?}

The success of a community library depends on its ability to effectively assess local needs and respond to them. KCL was sensitive and responsive to individual and collective needs of women in the community. It consulted with the women and sought to accommodate their needs and interests. The women, however, did have suggestions for ways in which the KCL could better serve their (and their community's) needs. This section presents the women's ideas for an enhanced community library, as the author believes that it is important to heed their recommendations if there is a serious commitment to women's literacy programs.

\section{Increased library activities}

The women believed that in addition to the activities it currently offered, the library could also offer, for example, workshops and courses on "how to do crafts ... things to do to make money", health, and farming: "you know our place is based on agriculture ... so to bring more workshops on agriculture, so people can learn [about] ... poultry farming, pig farming, plant farming ... and even how to know to grow [different kinds of] greens". One woman saw the library as a site that offered potential for self-development and empowerment: "I want to learn the language [English] so that I can 
communicate others and read book ... and to communicate with others, communicate with the leaders ... that's what I want."

\section{Augmented resources}

All the women who participated in this study, as most women living in Kyato village and other rural areas of Uganda, were farmers. For practical purposes, they were interested in learning more about crop diversity, husbandry, soil fertility and other agricultural topics to improve their farming methods and production. The library possessed a small number of books and other resources relating to agriculture which the women thought were sufficient for their needs. (However, it is likely that their assessment of the quality and quantity of the available material was largely due to the fact that their exposure to such texts was extremely minimal. Moreover, their literacy abilities - especially in English, the language of most of the texts - were low, and so they were not able to provide a very critical evaluation of these materials).

What the author found particularly interesting were the kinds of materials in which they were interested in having the library acquire, including books and magazines on "catering" (international cooking), hairstyles, fashion, entertainment, international events and novels. As $\mathrm{KCL}$ had few resources relating to these topics, the author printed off some recipes from the internet, purchased a few fashion magazines and showed the women how to find international news in the newspapers to which the library subscribed and used these events as topics of conversation in the literacy classes. The women were excited to have access to some resources that addressed their personal interests and that they felt comfortable perusing, and they sat together in groups, poring over the material, reading, talking and laughing. This strengthened a feeling of ownership and belonging with respect to the library, as they experienced a kind of personal connection with the library's content. As Cadbury and Mchombu $(2006,10)$ state: "... it is vital that potential library users are not alienated by libraries which only contain material that is too detailed, too advanced, or simply irrelevant to their needs."

Paying specific attention to the interests of library patrons strengthens the relationship between the institution and its members. It also directly engages newly literate members in literacy practices - skills, abilities and practices that can be transferred to different textual genres: "Apart from teaching literacy, the library has to focus its collection development on the needs of its neo-literate users. This means a strong focus is needed on the acquisition of relevant and interesting reading material for adults with low vocabulary or literacy skills." (Krolak, 2005, 8)

\section{Increased outreach}

Several of the women thought the library could do more in terms of community outreach in order to attract more active members. Their suggestions included:

- "to sensitise people to start using it more than they use it now."

- "sensitizing the ... men and involving them in these workshops and seminars ... when you involve them [the men] they can see what is happening."

- "empower this adult education."

\section{Conclusion}

At the 68th IFLA Council and General Conference in Glasgow, in 2002, Uno Nillson talked of the importance of "library power" based on his experiences of libraries in Zimbabwe:

[Library power] presents the possibility for all people to create his/her own picture of the society, of science, of culture and of the world ... to be able to read and to understand different kind of information in a critical way is basic for people's ability to make [up] their own minds and become educated ... [and] to see what is not there, to see reality not only as it is, but how it could be. (Nilsson 2002, 1)

This paper has highlighted the relationship between the Kyato Community Library and a group of women in the surrounding communities, demonstrating how the community library can serve as a rich and potent site of of learning, gathering, hope and empowerment. The author has stressed the need for the "community" aspect of community libraries to constitute a core referential for its resource acquisition, programming, and role within the community. Active outreach, and genuine attention paid to the literacy needs and desires of its members develops a sense of ownership amongst its members, which in terms strengthens support for the library as a valuable and respected institution within the community. With respect to women in particular, the community library can offer educational oppor- 
tunities that they have been denied in the past. In addition, the community library can constitute an important, safe, gathering place for women, where they can engage in discussions and activities of interest and importance to them. The women in this study demonstrated that the opportunities KCL offered to them inspired them to envision new ways in which KCL could further secure its role in the community and further empower all of its members. As Jessica stated: "[I] used to fear these young students at school ... but now [I feel] comfortable [in the library]".

\section{Acknowledgements}

I would like to express my deep gratitude to the strong and determined women who so generously and willingly shared their learning experiences with me. And I heartily thank research assistant and translator Daniel Ahimbisbwe, who was an integral part of the data collection for this study. I would also like to express my deep gratitude to my $\mathrm{PhD}$ Supervisors, Drs. Maureen Kendrick and Bonny Norton, who continue to guide and inspire me far beyond the completion of my PhD program. Thank you to Dr. Kate Parry and Dr. A.B.K. Kasozi for their support of, and assistance with my research. I would also like to thank Michele Roth for her valuable editorial and analytical input. I gratefully acknowledge funding support for this research from the Social Sciences and Humanities Research Council of Canada (SSHRC), and the International Development Research Centre of Canada (IDRC) and the University of British Columbia (Graduate Fellowship fund).

\section{Notes}

1. Pseudonyms are used for the names of villages, local institutions and research participants.

2. With permission, the author has used Mr. Daniel Ahimbisibwe's real name, in order to acknowledge publicly his invaluable work as translator and research assistant for this study.

3. The definition of "adequate" is deliberately vague, as it reflects the range and nature of girls and women who whose education has been truncated or denied completely. For the purposes of this paper, the author is working with indicators that show that in general women receive less educational opportunities than men and therefore that it is likely that there is a bigger gap between the educational aspirations and actual achievements of women than there is for men.

\section{References}

Aitchison, J. 2006. Experiments in the provision of rural community libraries in South Africa: the Family Literacy Project's initiatives. Innovation 32: 94-109. URL: http:// familyliteracyproject.co.za/knowledge.html\#publications [viewed 22 April 2009]

Cadbury, N., \& K. Mchombu. 2006. Libraries, literacy and poverty reduction: a key to African development: a paper commissioned by Book Aid International and sponsored by the Commonwealth Foundation. London: Book Aid International. URL: http:// eprints.rclis.org/11044/ [viewed 22 April 2009]

Dent, V., \& L. Yannotta. 2005. A rural community library in Africa: A study of its use and users. Libri 55(1): 39-54. URL: http://librijournal.org/2005-1 toc.html [viewed 22 April 2009]

Jones, S. 2008. Secondary schooling for girls in rural Uganda: Challenges, opportunities and emerging identities. Unpublished doctoral dissertation. University of British Columbia, Canada.

Jones, S., \& B. Norton. 2007. On the limits of sexual health literacy: Insights from Ugandan schoolgirls. Journal of Diaspora, Indigenous and Minority Education 1(4): 285-305.

Jones, S., \& B. Norton. (in press). Sexual health literacy, gender, and HIV/AIDS. In: C. Higgins \& B. Norton (Eds.), Applied Linguistics in the Field: Local Knowledge and HIVIAIDS. Multilingual Matters. (Critical Language and Literacy Studies series): Bristol, UK

Kendrick, M. \& S. Jones. 2008. Girls' visual representations of literacy in a rural Ugandan community. Canadian Journal of Education 31(2): 371-404.

Kendrick, M., S. Jones, H. Mutonyi, \& B. Norton. 2006. Multimodality and English education in Ugandan schools. English Studies in Africa 49(1): 95-114.

Kendrick, M., S. Jones, H. Mutonyi, \& B. Norton. (forthcoming). Using Drawing, Photography, and Drama to Enhance students' English Language Learning in Uganda. In: M. Dantas-Whitney, \& S. Rilling, (Eds.), Authenticity in the language classroom and beyond: Children and adolescent learners. Alexandria, VA, USA: TESOL.

Krolak, L. 2005. The role of libraries in the creation of literate environments. Background paper prepared for the Education for All Global Monitoring Report 2006 Literacy for Life UNESCO. URL: http://portal.unesco.org/education/en/ev. php-URL_ID $=43317 \& U R L$ DO=DO_TOPIC\&URL_SEC TION $=201 . \mathrm{html}$ [viewed 13 May 2009]

Mlama, P. 2005. Gender and education for rural people. Working document for the Ministerial Seminar on Education for Rural People in Africa: Policy Lessons, Options and Priorities. Paper presented at the FAO/UNESCO/ADEA Workshop (Sept. 2005), Addis Ababa. New York: Forum for African Women Educationalists/Carnegie Corporation. URL: http:// www.fao.org/SD/ERP/addisababa/Papers/EQUITY\%20ISSUES $\% 20$ gender $\% 20$ and $\% 20$ education $\% 20$ in $\% 20$ rura$1 \% 20$ areas\%20with\%20cover.doc [viewed 15 May 2009]

Mostert, BJ. 1998. Community libraries: the concept and its application - with particular reference to a South African library system. International Information and Library Review 30: $71-85$.

Mostert, BJ. 2001. African public library systems: a literature survey. LIBRES 11(1). URL: http://libres.curtin.edu.au/li bres11n1/mostert.htm [viewed 22 April 2009] 
Nawe, J. 2001. The future of library and information services in Tanzania. Library Review 50(3): 128-145.

Nilsson, U. 2002. The role of libraries in a developing society - a Zimbabwean experience. Paper presented at the $68^{\text {th }}$ IFLA Council and General Conference, August 18-24, Glasgow. URL: http://www.ifla.org/IV/ifla68/papers/080-092e.pdf [viewed 22 April 2009]

Nussbaum, MC. 2003a. Capabilities as Fundamental Entitlements: Sen and Social Justice. Feminist Economics, 9 (2-3): 33-59.

Nussbaum, M. C. 2003b. Women's Education: a Global Challenge. Signs: Journal of Women and Culture in Society. 29(2): 325-355.

Robeyns, I. 2006. Three Models of Education: Rights, Capabilities and Human Capital. Theory and Research in Education 4(1): 69-84.

Robinson-Pant, A. 2004. Introduction. In: Robinson-Pant, A. (Ed.), Women, Literacy, and Development: Alternative Perspectives, 1-9. London, UK: Routledge.

Saito, M. 2003. Amartya Sen's Capability Approach to Education: A Critical Exploration. Journal of Philosophy of Education, 37(1): 17-33.

Sen, A.K. 1999. Development as Freedom. New York, NY, USA: Anchor Books.

\section{Editorial history:}

Paper received 10 January 2009;

Accepted 9 March 2009.
Sturges, P. 2001. The poverty of librarianship: an historical critique of public librarianship in Anglophone Africa. Libri 51(1): $38-48$.

Sturges, P. 2004. Demons, disease and the library in Africa. Focus on international library and information work 35(3): $100-$ 109.

Sturges, P., \& P. Gooch. 2006. Information services and the irrational. Information Development 22(1): 26-31.

Subrahmanian, R. 2005. Gender Equality in Education: Definitions and Measurements. International Journal of Educational Development, 25: 395-407.

Uganda Bureau of Statistics (UBS). 2002. Kampala, Masaka, Mpigi, Mubende and Mukono districts: Socio Economic conditions based on the 1999/2000 Uganda National Household Survey. Entebbe, Uganda: Uganda Bureau of Statistics.

Unterhalter, Elaine. 2005. Fragmented Frameworks? Researching Women, Gender, Education and Development. In: Aikman, S. \& E. Unterhalter, (Eds.), Beyond Access: Transforming Policy and Practice for Gender Equality in Education, 15-35. Oxford: OXFAM. URL: http://publications.oxfam. org.uk/oxfam/display.asp isbn $=0855985291$ [viewed 22 April 2009] 


\section{COPYRIGHT INFORMATION}

TITLE: The Community Library as Site of Education and Empowerment for Women: I

SOURCE: Libri 59 no2 Je 2009

PAGE(S): 124-33

The magazine publisher is the copyright holder of this article and it is reproduced with permission. Further reproduction of this article in violation of the copyright is prohibited. To contact the publisher:

http://www.librijournal.org/ 